\title{
Multipotency and secretome: the mechanisms behind the regenerative potential of adipose-derived stem cells
}

\author{
Doruk Orgun, Hiroshi Mizuno \\ Department of Plastic and Reconstructive Surgery, Juntendo University School of Medicine, Tokyo 113-8421, Japan.
}

Correspondence to: Dr. Hiroshi Mizuno, Department of Plastic and Reconstructive Surgery, Juntendo University School of Medicine, 2-1-1 Hongo Bunkyo-ku, Tokyo 113-8421, Japan.E-mail: hmizuno@juntendo.ac.jp

How to cite this article: Orgun D, Mizuno H. Multipotency and secretome: the mechanisms behind the regenerative potential of adipose-derived stem cells. Plast Aesthet Res 2017;4:32-40.

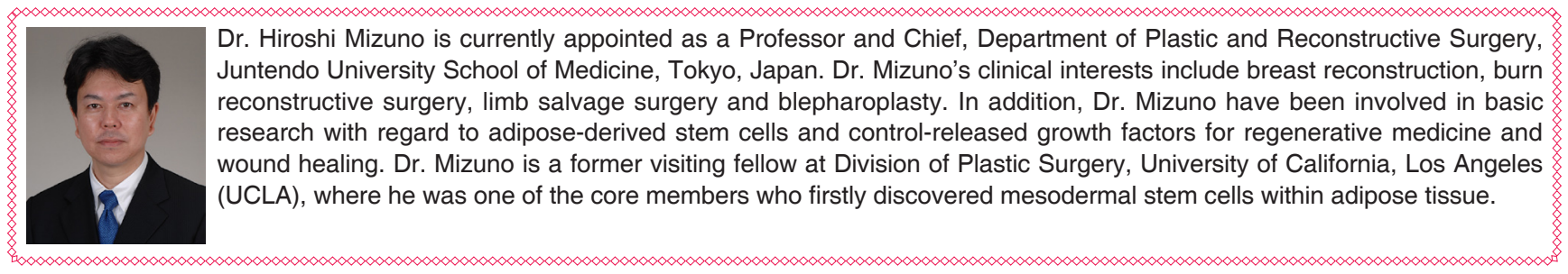

Article history:

Received: 23-12-2016

Accepted: 09-03-2017

Published: 22-03-2017

Key words:

Stem cell transplantation,

paracrine communication,

angiogenesis,

wound healing,

radiation injuries,

macrophages (M2 subtype)

\begin{abstract}
The use of stem cells for regenerating damaged organs and tissues which are unable to heal on their own is a widely studied field in plastic and reconstructive surgery as well as medicine in general. Among various stem cell types, adipose-derived stem cells (ASCs) are especially considered to be an ideal stem cell population for several clinical situations. These cells could be harvested from fat with relatively less invasive methods with high yield rates. ASCs have proved to be worthy of more research to understand the mechanisms behind their regenerative abilities. However, it remains uncertain if ASCs show their main effects by their multipotency, or by secreting abundant amounts of cytokines and growth factors. The authors have performed a review of the current publications and literature on the ASCs' immunophenotypical properties and isolation methods as well as basic and clinical science research about the mechanisms behind their regenerative effects. The purpose of this article is to synthesize information regarding ASCs' paracrine effects and their ability to differentiate into other cell lines, comparing these aspects in order to lead future research for a more effective cell therapy utilizing these cells.
\end{abstract}

\section{INTRODUCTION}

The concepts of creation and construction have always fascinated us human beings. With better understanding of human body, we also began to feel a powerful and passionate desire to simulate and recreate the phenomenon of this very complex existence to satisfy our curiosity, and also as physicians to heal.

The innate regeneration capacity of various tissues led

cc) (1) (2) This is an open access article distributed under the terms of the Creative Commons AttributioncC) $\mathrm{BY}$ NC SA NonCommercial-ShareAlike 3.0 License, which allows others to remix, tweak, and build upon the work non-commercially, as long as the author is credited and the new creations are licensed under the identical terms.

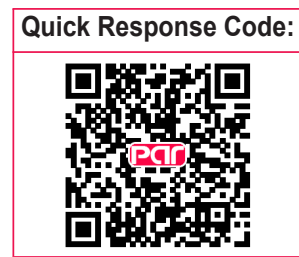


researchers to channel their effort to understand this phenomenon and the discovery of stem cells. After the discovery of mesenchymal stem cells (MSCs) in the bone marrow by Becker et al. ${ }^{[1]}$ in the 1960s, a new discipline called regenerative medicine has emerged. Many stem cell lines have been discovered since, but information about most of these is limited due to problems of availability, viability or potential risks. However, adipose tissue has proved to be an abundant and easily accessible source of multipotent stem cells. This cell population, named adipose-derived stem cells (ASCs) has been demonstrated to be widely available, viable and safe. The potential of ASCs administration has gained much interest for the conditions with limited or pathological repair of tissue damage caused by various insults.

Since the discovery of ASCs more than 10 years ago, ${ }^{[2]}$ their intrinsic properties suggesting similarity to other known MSCs such as bone marrow MSCs (BM-MSCs) were demonstrated, and currently ASCs are accepted to be MSCs. The abundance of these cells in fat tissue and the relative simplicity of harvesting fat from patients with procedures such as liposuction have made these cells a primary interest for plastic surgeons. There is a tremendous focus on using stromal vascular fraction (SVF) or isolated ASCs as a regenerative therapy method for chronic wounds or for the reconstruction of tissue defects after oncological tumor resection, as well as to achieve effective fat grafting or as a skin rejuvenating product in aesthetic surgical practice. There are active clinical trials investigating the effects of ASC or SVF administration on several pathological conditions..$^{[3,4]}$ This clinical activity is predicted to expand in the future.

It is becoming more acknowledged that ASCs have a promising therapeutic potential for a broad spectrum of medical conditions. We have previously reviewed the literature on the properties of ASCs and their capacity as a tool of regenerative medicine.$^{[5-7]}$ Recently, a new debate on the regenerative effects of these cells has been introduced. It is still not clear if ASCs show their main effects directly by differentiating into mature cells (e.g. osteocytes) at the site of implantation, or by their paracrine arsenal of many prominent growth factors to promote regeneration/remodeling and modulate inflammation in the tissue. We have performed a literature review of basic and clinical science regarding this subject using the PubMed and Cochrane databases using "ASCs" and "phenotype" or "isolation" or "angiogenesis" or "wound healing" or "radiation injury" or "immune regulation". A total of 118 articles were reviewed regarding ASCs' immunophenotypical properties and methods of isolation, as well as their effects on vascular diseases, angiogenesis, radiation injury and chronic wounds including diabetic ulcers. Interaction of ASCs with cells of the immune system was also investigated. Articles with detailed information on ASCs' molecular interactions with other cells were eligible for inclusion. Duplicate/similar studies and studies without information on ASCs' effects at the molecular level were excluded.

\section{THE IMMUNOPHENOTYPIC PROPERTIES OF ASCS}

The immunophenotyping and isolation protocols for the ASCs are still not standardized. Without a universal protocol, comparison of experimental data and future advances are difficult. In order to achieve a consensus for isolating ASCs, International Federation for Adipose Therapeutics and Science and International Society for Cell Therapy have published a joint statement about the phenotypic properties of these cells as well as SVF cells. ${ }^{[8]}$

SVF is a substance which consists not only of ASCs but also endothelial cells, erythrocytes, fibroblasts, lymphocytes, monocyte/macrophages and pericytes. ${ }^{[9]}$ The substance of cells in SVF is usually named as "SVF cells". These SVF cells are identified as being negative for CD235a and sometimes CD31, yet positive for CD34 or CD45. Further passaging depletes most of the hematopoietic cells and alters the immunophenotype of the remaining cell population, which are mostly ASCs. These culture expanded ASCs are positive for CD34 (could be negative in further expansions), CD44, CD73, CD90 and CD105 like other MSCs and negative for CD31 and CD45 [Figure 1]. ${ }^{[10,11]}$ ASCs are different from BM-MSCs since they are positive for CD36 (GPIIlb) and negative for CD106 (vascular cell adhesion molecule-1). ${ }^{[12,13]}$

It is also known that ASCs lose CD34 expression over time with consecutive passaging. ${ }^{[14]}$ Additionally, ASCs eventually senesce with consecutive passaging due to the low telomerase activity. ${ }^{[15]}$ This might lead the researcher to acquire inaccurate results if senescent cells of latter passages are used. For the reliability and standardization of the experiments, it is also advised that the ASCs' multilineage (i.e. adipocytes, chondrocytes and osteoblasts) differentiation potential should be demonstrated, which is now a common practice.

\section{ISOLATION OF ASCS}

Since the application of ASCs/SVF is becoming increasingly common, there is focused interest on efficient isolation and preparation of ASCs from 


\section{Adipose tissue harvest}

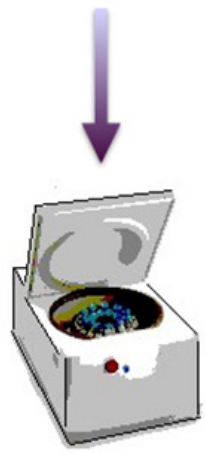

\section{Centrifugation: $300 \mathrm{~g}$ for $5 \mathrm{~min}$}

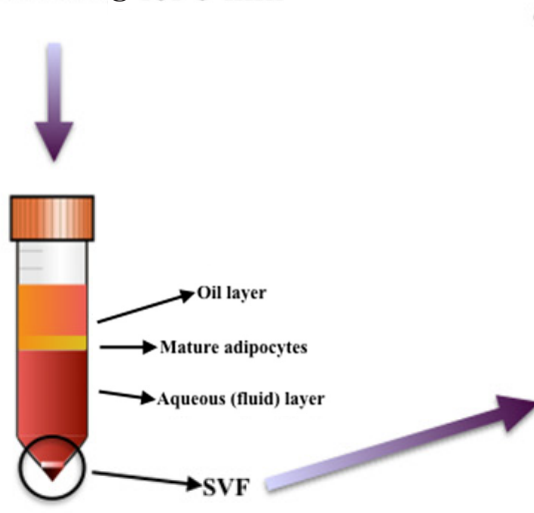

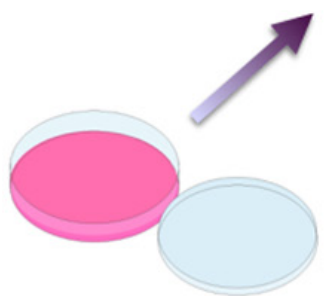

Culture expansion

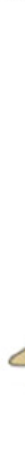

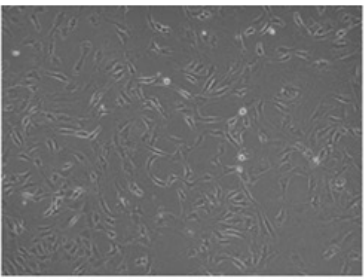

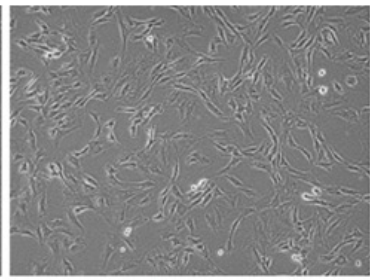

ASC

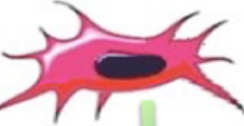

ASCs

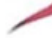

CD31 (-) CD34 (-/+)

CD45 (-)

CD73 (+)

CD90 (+)

CD105 (+)

CD31 (-/+)

CD34(+)

CD45 (+)

CD73 (-/+)

CD90 $(-/+) \rightarrow$ due to other populations

CD105 (-/+) $\star$

Figure 1: The phenotypic differences between SVF cells and culture expanded ASCs. ASCs: adipose-derived stem cells; SVF: stromal vascular fraction

adipose tissue. Liposuction is the most widely used method to harvest fat from humans. The liposuction aspirate is primarily composed of fragmented fat, blood and saline. ASCs are usually isolated from the fatty portion. A previous study showed that isolation of ASCs from the liposuction aspirate fluid (LAF) portion is also possible, but unfortunately this method yields less cells. ${ }^{[14]}$

The investigation for new methods to increase efficiency of ASC isolation also needs to be mentioned. Conventional methods to acquire SVF or ASCs take a long time, making the process costly and increasing the risk of contamination. Sachs et al. ${ }^{[15]}$ and Francis et al. ${ }^{[16]}$ isolated viable ASCs from liposuction aspirate within thirty minutes without using collagenase digestion; however, the cell yield was much less compared to conventional isolation method. In another study, it is suggested that using fluorescent assisted cell sorting (FACS) for ASCs isolation is possible, however this method also yields less cells. ${ }^{[17]}$

Schipper et al. ${ }^{[18]}$ investigated whether the region of harvest or the age of the donor had effects on ASCs' function. Results of the study showed no statistically significant difference in terms of yield or function of ASCs harvested from different locations. Jurgens et al..[19] compared ASCs harvested from abdomen versus hip/ thigh region, and similarly no significant difference in the yield and function of ASCs was found. Gnanasegaran et al. ${ }^{[20]}$ has investigated whether the harvesting procedure affects isolated ASCs. They argued that cells harvested using liposuction had endodermal propensity while cells harvested by excision had meso/ectodermal propensity.

Preservation of human ASCs for further use is another subject which is being investigated. According to Shah et al. ${ }^{[21]}$ colony forming potential and cell marker expression of ASCs except CD34 and CD45 did not change with cryopreservation; however, their differentiation potential was significantly reduced. Further investigation on this subject is necessary.

\section{THE EFFECTS OF ASCS ON ANGIOGENESIS}

There is a considerable amount of research on the angiogenic effects of ASCs against ischemic diseases. 
A fraction of these studies initiated by plastic surgeons attempt to utilize the angiogenic potential of ASCs primarily to introduce effective treatment modalities for debilitating chronic wounds. ASCs have shown to induce angiogenesis and increase the survival of ischemic tissues in these preclinical studies. The exact mechanisms for these phenomena are not well established, but it is suggested that the release of proangiogenic growth factors by ASCs could be mainly responsible.

There is also evidence that ASCs could integrate into tubular structures in vivo and express CD31, a marker for endothelial cells. ${ }^{[22]}$ However, there is no evidence that ASCs could directly differentiate into proper endothelium or fully functional blood vessels.

Suga et al. ${ }^{[23]}$ implanted green fluorescent protein (GFP) expressing ASCs into ischemic inguinal fat pads of mice in order to investigate their fate. They found out that although the transplanted ASCs gradually diminished after implantation, there was less tissue atrophy and higher vascular density in the ASC treated group compared with control. Tissue expression of vascular endothelial growth factor (VEGF) and hepatocyte growth factor (HGF) were also found to be higher.

Several studies on cardiac regeneration also revealed the importance of paracrine secretions of ASCs. Sadat et al. ${ }^{[13]}$ documented that ASCs have cardioprotective effects via secretion of insulin like growth factor-I (IGF-I) and VEGF. Another study by Cai et al. ${ }^{[24]}$ suggests that the improvement seen with the administration of ASCs after myocardial infarction (MI) is not due to the cardiomyocyte differentiation of ASCs but due to their ability to augment angiogenesis by paracrine mechanisms. They showed that the density of newly formed vessels in the developing infarct was significantly higher in the group treated with ASCs. This is supported by the results of another study which demonstrated that the post-MI administration of ASCs augmented vessel density and prevented abnormal remodeling of the infarct area in pigs. ${ }^{[25]}$ Transplanted ASCs failed to stay engrafted in the myocardium, suggesting that their indirect paracrine effects could be responsible for the improved outcome.

Another study showed that ASCs implanted in ischemic hind limb of mice neither differentiate into endothelial cells nor integrate into the host capillary vasculature, however promote angiogenesis and formation of collateral vessels with amplified angiogenic signals (via VEGF/mTOR/Akt pathway). Similarly, these cells show low survival rates when implanted, which once again supports that the regenerative effects could be due to their paracrine abilities. ${ }^{[26]}$

There are also several studies which investigated the effects of ASCs administration on renovascular diseases. Administration of ASCs in pigs with renal artery stenosis restored renal hemodynamics and function. In addition, increased VEGF levels, angiogenesis promotion and normalized vessel diameters were observed in the renal tissue. ${ }^{[27]}$

In our recent studies, we have also acquired results which convinced us that growth factor secretion by ASCs is quite important. Our group has demonstrated that the osteogenic regeneration potential of ASCs combined with platelet rich plasma (PRP) was greater than ASCs alone. ${ }^{[28]}$ In vitro studies showed that ASCs increased concentrations of transforming growth factor beta-1 (TGF-ß1), VEGF, IGF-1 and HGF when co-cultured with PRP. We concluded that improved osteogenesis could be related to increased growth factor secretion. Moreover, co-administration of ASCs with basic fibroblast growth factor (bFGF) on murine ischemic hindlimbs resulted in increased angiogenesis and the enhancement of blood flow to the ischemic limb. Secretion of several angiogenic growth factors was enhanced with bFGF, suggesting that a possible positive feedback mechanism might be responsible for the enhancement of blood flow to the ischemic limbin this study. ${ }^{[29]}$

External changes in physiological factors also seem to be influencing the paracrine abilities of ASCs. Rehman et al. ${ }^{[30]}$ demonstrated that, when cultured in hypoxic conditions, VEGF secretion of ASCs increases by 5 -fold. The conditioned media obtained from ASCs cultured in hypoxic conditions are found to be superior in enhancing endothelial cell growth compared with media obtained from ASCs cultured in normal conditions. This might be due to an increased secretion of growth factors by ASCs in hypoxic conditions.

The effects of ASCs transplantation on flap viability have also been investigated in detail. ${ }^{[31]}$ Suartz et al.. ${ }^{[32]}$ has showed that ASCs injection increased the viability of random pattern dorsal skin flaps in rats. This application also seems to increase the viability of interpolation flaps and reduce the time until pedicle division, due to increased vascularity of the flap. ${ }^{[33]}$ Our group also demonstrated that ASCs treatment improves the survival of flaps with venous congestion or provides protection against ischemia-reperfusion injury. ${ }^{[34]}$ Moreover, when the ASCs were preconditioned in hypoxic conditions then implanted to skin flaps, they were shown to increase flap survival. This phenomenon is thought to be due to the increased release of VEGF 
and hypoxia inducible factor-1a (HIF-1a) by the preconditioned ASCs. ${ }^{[35]}$

There have been several clinical studies conducted on human patients as well. Lee et al. ${ }^{[36]}$ investigated the clinical safety of ASCs administration in patients with critical limb ischemia. Two thirds of the patients showed significant clinical improvement by complete wound healing and formation of collateral vessels in the affected area. There were no side effects or undesirable outcomes after treatment. The authors suggested that the improvement was due to the angiogenic paracrine properties of ASCs; however, the lack of histological and molecular evaluation of the results deems it impossible to offer a clear scientific explanation. Even though the beneficial effects of ASCs such as their differentiation capacity and secretion of pro-angiogenic factors are confirmed in vitro, the exact mechanisms for their in vivo activity are not well established. More clinical studies are needed to fully comprehend the therapeutic abilities of ASCs in wound healing in order to construct standardized treatment modalities in the future.

\section{THE EFFECTS OF ASCs ON WOUND HEALING}

Chronic wounds are a prominent health issue all around the world and the management of these wounds is challenging. Diabetic ulcers, venous ulcers and pressure ulcers represent $80-90 \%$ of all chronic wounds. ${ }^{[37]}$ Even with optimal conditions, the healing process mostly leads to scarring and fibrosis. Many cases fail to heal and lead to amputations of the lower extremity, which are very debilitating for the patient. In addition, these wounds usually have superposed infection, and if not treated correctly may lead to sepsis or even death. ${ }^{[38]}$ The importance and high prevalence of chronic wounds provoked numerous investigations in order to find a better treatment for these wounds. The positive effects of ASCs on wound healing inchronic and complex wounds (such as anorectal fistula due to Crohn disease) have been well demonstrated. ${ }^{[39]}$ It is critical to consider that the animal wound models used in these studies are different than human wounds in many aspects; however, the results are promising.

There is evidence that ASCs could be contributing to the healing of both mesodermal (i.e. dermis) and ectodermal (i.e. keratinocytes) derived tissues in the wound. ${ }^{[40]}$ The interaction between ASCs and keratinocytes has been a subject of interest and a fair amount of investigation has been done regarding this issue. Ozpur et al. ${ }^{[41]}$ has demonstrated that the administration of a fibrin matrix seeded with both
ASCs and keratinocytes led to epithelialization of full thickness wounds with minimal wound contracture. The authors claimed that this improvement in wound healing was due to the paracrine secretions of ASCs. Moreover, co-administration of acellular conditioned medium (CM) from ASCs cultures with PRP increased keratinocyte and fibroblast proliferation, ${ }^{[42]}$ as well as keratinocyte maturation. ${ }^{[43]}$

There is also evidence that ASCs could differentiate into keratinocyte-like cells and express keratinocyte specific markers when co-cultured on a fibroblast layer. $^{[44,45]}$

Zografou et al. ${ }^{[46,47]}$ have investigated the effects of transplanted autologous ASCs on full thickness skin graft survival and wound healing in diabetic rats. Graft survival was improved compared with control. Curiously, ASCs showed arrangement in tubular structures which were positively stained with both VEGF and von Willebrand Factor (vWF) staining in vivo. Increased tissue expression of TGF- $\beta 3$ and VEGF were shown in skin grafts with transplanted ASCs by the same group in another study.

There is also evidence that ASCs have lifesaving effects on the residing cells of tissues after an ischemic insult. A study by $\mathrm{HaO}$ et al. ${ }^{[48]}$ showed that transplantation of ASCs inhibited myocyte apoptosis in the ischemic muscle.

Unfortunately, topical or injected ASCs usually tend to stay in the applied location and fail to effectively migrate. The delivery method of ASCs to wounds has been a thoroughly investigated topic of great importance. Delivery systems which supply a favorable microenvironment for the ASCs to survive are suggested to increase their regenerative effects. For example, administration of ASCs to open wounds on a silk fibroin-chitosan scaffold accelerated wound closure and new vessel formation. ASCs delivered by the scaffold infiltrated into the proliferating epithelium and vascular tissue and expressed smooth muscle actin, also differentiated into cells similar to of the epidermal epithelium. ${ }^{[40]}$ Currently, scaffolds are also being used to induce differentiation of ASCs into specific cell lines. ${ }^{[49]}$

There is an increase of radiation injuries and wounds with the widespread use of radiotherapy, interventional radiological or cardiological procedures, and radioactive material intake for nuclear medicine related scans or treatments. Chronic radiation wounds usually cannot be treated with conventional methods such as flap surgery or skin grafting because of 
tissue ischemia and fibrosis. ${ }^{[50]}$ The ischemia is due to inadequate vasculature and incompetent vessels in irradiated tissues. The radiated skin shows erythema, teleangiectasia, abnormal pigmentation and dermal atrophy. Once a radiation wound is developed, it becomes more and more complicated with necrosis, infection, and fibrosis. ${ }^{[51]}$ These chronic radiation injuries however could improve by sufficient blood supply to the tissues since it is a well known fact that the microvasculature is of utmost importance for proper wound healing.

ASCs therapy is promising for the treatment of such wounds. ASCs residing in the irradiated tissue are susceptible to radiation injury, ${ }^{[52]}$ but can survive in an irradiated tissue if implanted after the radioactive insult. ASCs administration leads to improved blood perfusion, capillary density and VEGF levels in irradiated wounds. ${ }^{[22]}$ Viability of irradiated skin flaps increased when treated with ASC injection in correlation with increased vascularity in the flaps injected with ASC. ${ }^{[53]}$ At cellular level, ASCs were shown to stimulate fibroblast proliferation and increase the expression of several cytokines such as interleukin-6 (IL-6), bFGF and VEGF secreted by fibroblasts after radioactive insult. ${ }^{[54]}$

The literature is rich in terms of clinical applications of ASCs to cure radiation injury. Akita et al. ${ }^{[55]}$ injected ASCs to the chronic radiation wounds of 10 patients who received adjuvant radiotherapy after mastectomy. Autologous ASCs with human recombinant bFGF on an artificial dermis were applied on debrided radiation wounds of patients. It is known that MSCs are resistant to radiation. The angiogenic growth factor bFGF has proved to be very effective for patients with severe wounds. Human recombinant bFGF is clinically approved and widely used for the treatment of chronic wounds in Japan. Artificial skin substitutes provide a favorable environment for both internal and external cells and growth factors. This combination treatment led to complete healing of radiation wounds, lasting at least more than 1.5 years. In a similar study, Rigotti et al. ${ }^{[56]}$ investigated the effects of lipoaspirate administration into the radiation wounds of 20 patients who received adjuvant radiotherapy after mastectomy or quadrantectomy for breast cancer. Dramatic improvement of symptoms and complete healing of the wound was observed in all patients. This improvement is believed to be due to the proangiogenic paracrine effects of ASCs present in the lipoaspirate. Despite the encouraging clinical results, it should be noted that neither of these studies included a patient group without treatment for comparison. Future studies with randomized subjects are necessary for a higher level of evidence.
It is being more widely acknowledged that ASCs have revitalizing effects on stem-cell depleted tissues such as radiation wounds or ischemic fibrotic tissues. ${ }^{[57,58]}$ Administration of ASCs seems to improve vascularity and healing capacity for these morbid conditions. This matter is very promising since there are currently no effective treatments for these conditions.

\section{THE SYNERGISM BETWEEN ASCS AND MACROPHAGES AND THE IMMUNE REGULATORY EFFECTS OF ASCS}

Another recent focus of interest on ASCs research is the cells' relation to immunomodulation. ${ }^{[59]}$ Like any other cell, ASCs interact with other cells, and especially their relations with macrophages have recently become a topic of interest. It is known that there are two macrophage subsets; the M1 phenotype which has pro-inflammatory properties, and the M2 phenotype which has anti-inflammatory effects on tissue. ASCs are shown to interact especially with the M2 subset. ${ }^{[60,61]} \mathrm{M} 2$ macrophage activation by the interaction with ASCs improves the volume retention of fat grafts by stimulating angiogenesis. ${ }^{[62]}$ As an explanation of this observation, gene expression of several angiogenic cytokines, such as VEGF, HGF, bFGF, and stromal cell-derived factor-1 were found to be increased in the macrophages cultured in ASCs conditioned media. Additional studies documented that the host macrophage depletion significantly impairs ASCs mediated angiogenesis and ASCs mediated angiogenesis can be prevented with monoclonal antibody mediated blocking of IL-10 (a cytokine product of macrophages). ${ }^{[63]}$ It was also suggested that M2 macrophages play an important role in the ASCs mediated lymphangiogenesis. ${ }^{[4]}$ Taken together, these findings support the hypothesis that an existing association with ASCs and might be an important regulator of angiogenesis [Figure 2].

In addition, it was demonstrated that ASCs inhibit and decrease inflammatory cytokines and increase IL-10 levels in vivo by acting on macrophages. ${ }^{[64]}$ This suggests that ASCs might have immunomodulatory effects by regulating pro-inflammatory cytokine concentrations in the inflamed tissue. It is most likely due to this effect that ASCs transplantation in dystrophic muscles of dystrophin-deficient mice improved muscle strength and resistance to fatigue. ${ }^{[65]}$ It was also documented that ASCs transplantation induces macrophage migration and the secretions of ASCs are dependent on inflammatory cells. ${ }^{[66]}$

There are other studies regarding the interaction between ASCs and fibroblasts in the literature. 


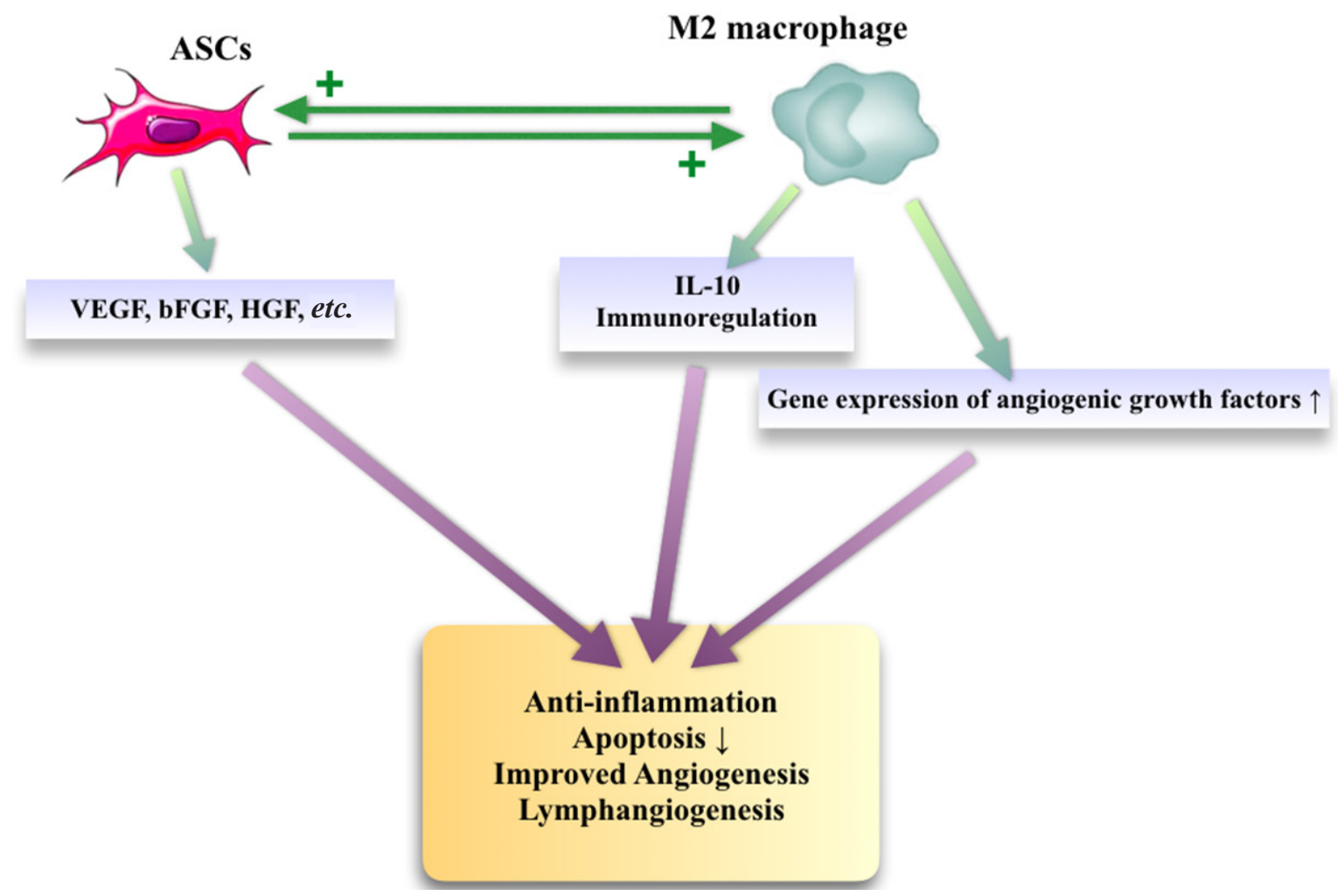

Figure 2: The interaction between ASCs and M2 macrophages. ASCs: adipose-derived stem cells; VEGF: vascular endothelial growth factor; bFGF: basic fibroblast growth factor; HGF: hepatocyte growth factor; IL-10: interleukin-10

Kim et al. ${ }^{[67]}$ showed that ASCs conditioned media promotes dermal fibroblast proliferation, suggesting the paracrine activation of fibroblasts by ASCs. The same fibroblasts cultured in ASCs conditioned media were found to secrete increased amounts of type I collagen, and their expression of ECM proteins were found to be augmented.These findings suggest that this interaction might be playing an important role in wound healing.

\section{SUMMARY}

Many tissues have "intrinsic" stem cells in a resting state, activated with injury in order to repair the damage. However, the number of these cells is usually very small for complete regeneration by differentiating into the harmed cell lines. Recent investigations suggest that most stem cell lines also secrete potent growth factors, and this indirect "paracrine" or "bystander" effect could be as important as their ability to differentiate in tissue regeneration. ${ }^{[68]}$ There is convincing evidence that the paracrine secretions by ASCs improve wound healing and angiogenesis. The data that we have obtained in our lab over the years in several experiments also suggest that the paracrine secretions of ASCs are extremely potent. We believe that an accurate knowledge of ASCs secretome and its effects will help us to establish ASCs as a more viable clinical therapy in the future.

\section{Authors' contributions}

Manuscript's preparation: D. Orgun

Manuscript's review: H. Mizuno

Concept and design: H. Mizuno

Literature search: D. Orgun

\section{Financial support and sponsorship}

None.

\section{Conflicts of interest}

There are no conflicts of interest.

\section{Patient consent}

Not applicable.

\section{Ethics approval}

All the procedures followed were in accordance with the ethical standards of the responsible com-mittee on human experimentation (institutional or regional) and with the Helsinki Declaration when reporting studies on human beings.

\section{REFERENCES}

1. Becker AJ, McCulloch EA, Till JE. Cytological demonstration of the clonal nature of spleen colonies derived from transplanted mouse marrow cells. Nature 1963;197:452-54.

2. Zuk PA, Zhu M, Mizuno H, Huang J, Futrell JW, Katz AJ, Benhaim P, 
Lorenz HP, Hedrick MH. Multilineage cells from human adipose tissue: implications for cell-based therapies. Tissue Eng 2001;7:211-28.

3. Nguyen A, Guo J, Banyard DA, Fadavi D, Toranto JD, Wirth GA, Paydar KZ, Evans GR, Widgerow AD. Stromal vascular fraction: a regenerative reality? Part 1: current concepts and review of the literature. J Plast Reconstr Aesthet Surg 2016;69:170-9.

4. Lindroos B, Suuronen R, Miettinen S. The potential of adipose stem cells in regenerative medicine. Stem Cell Rev Rep 2011;7:269-91.

5. Mizuno H, Tobita M, Uysal AC. Concise review: adipose-derived stem cells as a novel tool for future regenerative medicine. Stem Cells 2012;30:804-10.

6. Orbay H, Tobita M, Mizuno H. Mesenchymal stem cells isolated from adipose and other tissues: basic biological properties and clinical applications. Stem Cells Int 2012;2012:461718.

7. Tobita M, Orbay H, Mizuno H. Adipose-derived stem cells: current findings and future perspectives. Discov Med 2011;11:160-70.

8. Bourin P, Bunnell BA, Casteilla L, Dominici M, Katz AJ, March KL, Redl H, Rubin JP, Yoshimura K, Gimble JM. Stromal cells from the adipose tissue-derived stromal vascular fraction and culture expanded adipose tissue-derived stromal/stem cells: a joint statement of the International Federation for Adipose Therapeutics and Science (IFATS) and the International Society for Cellular Therapy (ISCT). Cytotherapy 2013;15:641-8.

9. Alexander RW. Biocellular regenerative medicine: use of adiposederived stem/stromal cells and its native bioactive matrix. Phys Med Rehabil Clin N Am 2016;27:871-91.

10. Minteer DM, Marra KG, Rubin JP. Adipose stem cells: biology, safety, regulation, and regenerative potential. Clin Plast Surg 2015;42:169-79.

11. Bajek A, Gurtowska N, Olkowska J, Kazmierski L, Maj M, Drewa T. Adipose-derived stem cells as a tool in cell-based therapies. Arch Immunol Ther Exp (Warsz) 2016;64:443-54.

12. Nakagami H, Morishita R, Maeda K, Kikuchi Y, Ogihara T, Kaneda Y. Adipose tissue-derived stromal cells as a novel option for regenerative cell therapy. J Atheroscler Thromb 2006;13:77-81.

13. Sadat S, Gehmert S, Song YH, Yen Y, Bai X, Gaiser S, Klein H, Alt E. The cardioprotective effect of mesenchymal stem cells is mediated by IGF-I and VEGF. Biochem Biophys Res Commun 2007;363:674-9.

14. Yoshimura K, Shigeura T, Matsumoto D, Sato T, Takaki Y, AibaKojima E, Sato K, Inoue K, Nagase T, Koshima I, Gonda K. Characterization of freshly isolated and cultured cells derived from the fatty and fluid portions of liposuction aspirates. J Cell Physiol 2006;208:64-76.

15. Sachs PC, Francis MP, Zhao M, Brumelle J, Rao RR, Elmore LW, Holt SE. Defining essential stem cell characteristics in adiposederived stromal cells extracted from distinct anatomical sites. Cell Tissue Res 2012;349:505-15.

16. Francis MP, Sachs PC, Elmore LW, Holt SE. Isolating adiposederived mesenchymal stem cells from lipoaspirate blood and saline fraction. Organogenesis 2010;6:11-4.

17. Shah FS, Wu X, Dietrich M, Rood J, Gimble JM. A non-enzymatic method for isolating human adipose tissue-derived stromal stem cells. Cytotherapy 2013;15:979-85.

18. Schipper BM, Marra KG, Zhang W, Donnenberg AD, Rubin JP. Regional anatomic and age effects on cell function of human adiposederived stem cells. Ann Plast Surg 2008;60:538-44.

19. Jurgens WJ, Oedayrajsingh-Varma MJ, Helder MN, Zandiehdoulabi B, Schouten TE, Kuik DJ, Ritt MJ, van Milligen FJ. Effect of tissueharvesting site on yield of stem cells derived from adipose tissue: implications for cell-based therapies. Cell Tissue Res 2008;332:415-26.

20. Gnanasegaran N, Govindasamy V, Musa S, Kasim NH. Different isolation methods alter the gene expression profiling of adipose derived stem cells. Int J Med Sci 2014;11:391-403.

21. Shah FS, Li J, Zanata F, Curley JL, Martin EC, Wu X, Dietrich M, Devireddy RV, Wade JW, Gimble JM. The relative functionality of freshly isolated and cryopreserved human adipose-derived stromal/ stem cells. Cells Tissues Organs 2016; DOI: 10.1159/000446494.

22. Ebrahimian TG, Pouzoulet F, Squiban C, Buard V, André M, Cousin B, Gourmelon P, Benderitter M, Casteilla L, Tamarat R. Cell therapy based on adipose tissue-derived stromal cells promotes physiological and pathological wound healing. Arterioscler Thromb Vasc Biol 2009;29:503-10.

23. Suga H, Glotzbach JP, Sorkin M, Longaker MT, Gurtner GC. Paracrine mechanism of angiogenesis in adipose-derived stem cell transplantation. Ann Plast Surg 2014;72:234-41.

24. Cai L, Johnstone BH, Cook TG, Tan J, Fishbein MC, Chen PS, March KL. IFATS collection: human adipose tissue-derived stem cells induce angiogenesis and nerve sprouting following myocardial infarction, in conjunction with potent preservation of cardiac function. Stem Cells 2009;27:230-7.

25. Mazo M, Hernández S, Gavira JJ, Abizanda G, Araña M, LópezMartínez T, Moreno C, Merino J, Martino-Rodríguez A, Uixeira A, García de Jalón JA, Pastrana J, Martínez-Caro D, Prósper F. Treatment of reperfused ischemia with adipose-derived stem cells in a preclinical swine model of myocardial infarction. Cell Transplant 2012;21:272333.

26. Fan W, Sun D, Liu J, Liang D, Wang Y, Narsinh KH, Li Y, Qin X, Liang J, Tian J, Cao F. Adipose stromal cells amplify angiogenic signaling via the VEGF/mTOR/Akt pathway in a murine hindlimb ischemia model: a 3D multimodality imaging study. PLoS One 2012;7:e45621.

27. Eirin A, Zhu XY, Krier JD, Tang H, Jordan KL, Grande JP, Lerman A, Textor SC, Lerman LO. Adipose tissue-derived mesenchymal stem cells improve revascularization outcomes to restore renal function in swine atherosclerotic renal artery stenosis. Stem Cells 2012;30:1030-41.

28. Tajima S, Tobita M, Orbay H, Hyakusoku H, Mizuno H. Direct and indirect effects of a combination of adipose-derived stem cells and platelet-rich plasma on bone regeneration. Tissue Eng Part A 2015;21:895-905.

29. Horikoshi-Ishihara H, Tobita M, Tajima S, Tanaka R, Oshita T, Tabata Y, Mizuno H. Coadministration of adipose-derived stem cells and control-released basic fibroblast growth factor facilitates angiogenesis in a murine ischemic hind limb model. J Vasc Surg 2016;64:1825-34.

30. Rehman J, Traktuev D, Li J, Merfeld-Clauss S, Temm-Grove CJ, Bovenkerk JE, Pell CL, Johnstone BH, Considine RV, March KL. Secretion of angiogenic and antiapoptotic factors by human adipose stromal cells. Circulation 2004;109:1292-8.

31. Foroglou P, Karathanasis V, Demiri E, Koliakos G, Papadakis M Role of adipose-derived stromal cells in pedicle skin flap survival in experimental animal models. World J Stem Cells 2016;8:101-5.

32. Suartz CV, Gaiba S, França JP, Aloise AC, Ferreira LM. Adiposederived stem cells (ADSC) in the viability of a random pattern dorsal skin flap in rats. Acta Cir Bras 2014;29 Suppl 3:2-5.

33. Lu F, Mizuno H, Uysal CA, Cai X, Ogawa R, Hyakusoku H. Improved viability of random pattern skin flaps through the use of adiposederived stem cells. Plast Reconstr Surg 2008;121:50-8.

34. Uysal AC, Mizuno H, Tobita M, Ogawa R, Hyakusoku H. The effect of adipose-derived stem cells on ischemia reperfusion injury: immunohistochemical and ultrastructural evaluation. Plast Reconstr Surg 2009; 124:804-15.

35. Yue Y, Zhang P, Liu D, Yang JF, Nie C, Yang D. Hypoxia preconditioning enhances the viability of ADSCs to increase the survival rate of ischemic skin flaps in rats. Aesthetic Plast Surg 2013;37:159-70

36. Lee HC, An SG, Lee HW, Park JS, Cha KS, Hong TJ, Park JH, Lee SY, Kim SP, Kim YD, Chung SW, Bae YC, Shin YB, Kim JI, Jung JS. Safety and effect of adipose tissue-derived stem cell implantation in patients with critical limb ischemia: a pilot study. Circ J 2012;76:1750-60. 
37. Demidova-Rice TN, Hamblin MR, Herman IM. Acute and impaired wound healing: pathophysiology and current methods for drug delivery, part 1: normal and chronic wounds: biology, causes, and approaches to care. Adv Skin Wound Care 2012;25:304-14.

38. Wieman TJ, Smiell JM, Su Y. Efficacy and safety of a topical gel formulation of recombinant human platelet-derived growth factor-BB (becaplermin) in patients with chronic neuropathic diabetic ulcers. A phase III randomized placebo-controlled double-blind study. Diabetes Care 1998;21:822-7.

39. Andjelkov K, Sforza M, Barisic G, Soldatovic I, Hiranyakas A, Krivokapic Z. A novel method for chronic anal fissure treatment: adipose derived regenerative cells - a pilot study. Colorectal Dis 2016; DOI: 10.1111/codi.13555.

40. Altman AM, Yan Y, Matthias N, Bai X, Rios C, Mathur AB, Song YH, Alt EU. IFATS collection: human adipose-derived stem cells seeded on a silk fibroin-chitosan scaffold enhance wound repair in a murine soft tissue injury model. Stem Cells 2009;27:250-8.

41. Ozpur MA, Guneren E, Canter HI, Karaaltin MV, Ovali E, Yogun FN, Baygol EG, Kaplan S. Generation of skin tissue using adipose tissuederived stem cells. Plast Reconstr Surg 2016;137:134-43.

42. Stessuk T, Puzzi MB, Chaim EA, Alves PC, de Paula EV, Forte A, Izumizawa JM, Oliveira CC, Frei F, Ribeiro-Paes JT. Plateletrich plasma (PRP) and adipose-derived mesenchymal stem cells: stimulatory effects on proliferation and migration of fibroblasts and keratinocytes in vitro. Arch Dermatol Res 2016;308:511-20.

43. Seo G, Oh E, Yun M, Lee JY, Bae JS, Joo K, Chae GT, Lee SB. Adipose-derived stem cell conditioned medium accelerates keratinocyte differentiation via the upregulation of miR-24. Exp Dermatol 2015;24:792-3.

44. Ghanavati Z, Orazizadeh M, Bayati V, Abbaspour MR, Khorsandi L, Mansouri E, Neisi N. Characterization of a three-dimensional organotypic co-culture skin model for epidermal differentiation of rat adipose-derived stem cells. Cell J 2016;18:289-301.

45. Seo BF, Kim KJ, Kim MK, Rhie JW. The effects of human keratinocyte coculture on human adipose-derived stem cells. Int Wound J 2016;13:630-5.

46. Zografou A, Papadopoulos O, Tsigris C, Kavantzas N, Michalopoulos E, Chatzistamatiou T, Papassavas A, Stavropoulou-Gioka C, Dontas I, Perrea D. Autologous transplantation of adipose-derived stem cells enhances skin graft survival and wound healing in diabetic rats. Ann Plast Surg 2013;71:225-32.

47. Zografou A, Tsigris C, Papadopoulos O, Kavantzas N, Patsouris E, Donta I, Perrea D. Improvement of skin-graft survival after autologous transplantation of adipose-derived stem cells in rats. J Plast Reconstr Aesthet Surg 2011;64:1647-56.

48. Hao C, Shintani S, Shimizu Y, Kondo K, Ishii M, Wu H, Murohara T. Therapeutic angiogenesis by autologous adipose-derived regenerative cells: comparison with bone marrow mononuclear cells. Am J Physiol Heart Circ Physiol 2014;307:H869-79.

49. Dai R, Wang Z, Samanipour R, Koo KI, Kim K. Adipose-derived stem cells for tissue engineering and regenerative medicine applications. Stem Cells Int 2016;2016:6737345.

50. Singh M, Alavi A, Wong R, Akita S. Radiodermatitis: a review of our current understanding. Am J Clin Dermatol 2016;17:277-92.

51. Akita S. Treatment of radiation injury. Adv Wound Care (New Rochelle) 2014;3:1-11.

52. Jeong W, Yang X, Lee J, Ryoo Y, Kim J, Oh Y, Kwon S, Liu D, Son D. Serial changes in the proliferation and differentiation of adipose-derived stem cells after ionizing radiation. Stem Cell Res Ther 2016;7:117.
53. Hasdemir M, Agir H, Eren GG, Aksu MG, Alagoz MS, Duruksu G, Saglam O, Karaöz E. Adipose-derived stem cells improve survival of random pattern cutaneous flaps in radiation damaged skin. J Craniofac Surg 2015;26:1450-5.

54. Haubner F, Muschter D, Pohl F, Schreml S, Prantl L, Gassner HG. A co-culture model of fibroblasts and adipose tissue-derived stem cells reveals new insights into impaired wound healing after radiotherapy. Int J Mol Sci 2015;16:25947-58.

55. Akita S, Akino K, Hirano A, Ohtsuru A, Yamashita S. Noncultured autologous adipose-derived stem cells therapy for chronic radiation injury. Stem Cells Int 2010;2010:532704.

56. Rigotti G, Marchi A, Galiè M, Baroni G, Benati D, Krampera M, Pasini A, Sbarbati A. Clinical treatment of radiotherapy tissue damage by lipoaspirate transplant: a healing process mediated by adiposederived adult stem cells. Plast Reconstr Surg 2007;119:1409-22.

57. Mashiko T, Wu SH, Feng J, Kanayama K, Kinoshita K, Sunaga A, Narushima M, Yoshimura K. Mechanical micronization of lipoaspirates: squeeze and emulsification techniques. Plast Reconstr Surg 2017;139:79-90.

58. Kuno S, Yoshimura K. Condensation of tissue and stem cells for fat grafting. Clin Plast Surg 2015;42:191-7.

59. Guo J, Nguyen A, Banyard DA, Fadavi D, Toranto JD, Wirth GA, Paydar KZ, Evans GR, Widgerow AD. Stromal vascular fraction: aregenerative reality? Part 2: mechanisms of regenerative action. $J$ Plast Reconstr Aesthet Surg 2016;69:180-8.

60. Mantovani A, Sica A, Sozzani S, Allavena P, Vecchi A, Locati M. The chemokine system in diverse forms of macrophage activation and polarization. Trends Immunol 2004;25:677-86.

61. Lee YH, Thacker RI, Hall BE, Kong R, Granneman JG. Exploring the activated adipogenic niche: interactions of macrophages and adipocyte progenitors. Cell Cycle 2014;13:184-90.

62. Phipps KD, Gebremeskel S, Gillis J, Hong P, Johnston B, Bezuhly M. Alternatively activated M2 macrophages improve autologous fat graft survival in a mouse model through induction of angiogenesis. Plast Reconstr Surg 2015;135:140-9.

63. Koh YJ, Koh BI, Kim H, Joo HJ, Jin HK, Jeon J, Choi C, Lee DH, Chung JH, Cho CH, Park WS, Ryu JK, Suh JK, Koh GY. Stromal vascular fraction from adipose tissue forms profound vascular network through the dynamic reassembly of blood endothelial cells. Arterioscler Thromb Vasc Biol 2011;31:1141-50.

64. González MA, Gonzalez-Rey E, Rico L, Büscher D, Delgado M. Adipose-derived mesenchymal stem cells alleviate experimental colitis by inhibiting inflammatory and autoimmune responses. Gastroenterology 2009;136:978-89.

65. Pinheiro $\mathrm{CH}$, de Queiroz JC, Guimarães-Ferreira L, Vitzel KF, Nachbar RT, de Sousa LG, de Souza-Jr AL, Nunes MT, Curi R. Local injections of adipose-derived mesenchymal stem cells modulate inflammation and increase angiogenesis ameliorating the dystrophic phenotype in dystrophin-deficient skeletal muscle. Stem Cell Rev 2012;8:363-74.

66. Hattori H, Ishihara M. Altered protein secretions during interactions between adipose tissue or bone marrow-derived stromal cells and inflammatory cells. Stem Cell Res Ther 2015;6:70.

67. Kim WS, Park BS, Sung JH, Yang JM, Park SB, Kwak SJ, Park JS. Wound healing effect of adipose-derived stem cells: a critical role of secretory factors on human dermal fibroblasts. J Dermatol Sci 2007;48:15-24.

68. Feisst V, Meidinger S, Locke MB. From bench to bedside: use of human adipose-derived stem cells. Stem Cells Cloning 2015;8:14962. 